Relations industrielles

Industrial Relations

\title{
Wages and Prices
}

\section{Maurice Lamontagne}

Volume 5, numéro 6, mars 1950

URI : https://id.erudit.org/iderudit/1023353ar

DOI : https://doi.org/10.7202/1023353ar

Aller au sommaire du numéro

\section{Éditeur(s)}

Département des relations industrielles de l’Université Laval

\section{ISSN}

0034-379X (imprimé)

1703-8138 (numérique)

Découvrir la revue

Citer cet article

Lamontagne, M. (1950). Wages and Prices. Relations industrielles / Industrial Relations, 5(6), 52-54. https://doi.org/10.7202/1023353ar

Tous droits réservés @ Département des relations industrielles de l’Université Laval, 1950
Ce document est protégé par la loi sur le droit d'auteur. L’utilisation des services d'Érudit (y compris la reproduction) est assujettie à sa politique d'utilisation que vous pouvez consulter en ligne.

https://apropos.erudit.org/fr/usagers/politique-dutilisation/ 


\title{
WAGES AND PRICES
}

\author{
Maurice Lamontagne
}

\section{Wages and inflation}

In many circles it is claimed that the inflation that trod upon the heels of the postwar economic adjustment can be attributed in large measure to the sharp rise in wages.

This pretention does not square with the facts.

To get a clear idea of what the facts are we must go back to 1946, for that year marks the transition from the wartime to the peacetime economy. At that time there were five different factors contributing to the behaviour of prices.

On the demand side we must note the tremendous backlog of consumers' needs built up during the war and pressing for fulfillment, the high level of both individual and business revenue, as well as the vast amount of fluid reserve savings accumulated. Because of this volume of unsatisfied needs and the sharply augmented buying power of consumers, demand attained an unprecedented level.

On the supply side the principal factor was the relative scarcity of scores of products, which persisted throughout the whole reconversion period. This scarcity, it will be recalled, affected nearly every sector of the economy.

These factors, left to themselves, would well have been able to bring on an inflation. And yet, though they had been in play since the beginning of the war, the rise of prices had been relatively feeble. It was left to the last factor, appearing in 1946, to change the situation completely: the removal of price controls.

Thus, although the scarcity of consumer goods and the increase of consumer buying power were at the basis of the postwar inflation, what really set the ball rolling was the disappearance of controls plus the desire of producers to jack up profits.

Once the initial and sudden rise of prices took place the other stages in the inflationary process had to follow. The primary price increase obliged workman in those same industries to ask for higher wages; this increased amount paid out to production personnel contributed to swell the production costs, which in turn served as motive for a new increase in prices, and so the inflationary spiral continued.
Thus increased wages and production costs followed the upward march of prices; they were the effects, not the cause; they enabled the inflationary process to continue but they did not set it in motion. In reality the only immediate cause of inflation was the disappearance of controls, which left the scarcity of consumer goods and the augmented consumer buying power to run their course unhampered.

\section{Criteria for determining wage changes}

It is not enough, however, just to ascertain that wage increases are not the basic cause of the inflation. We must further ask whether workers have received their just share of the returns from the price increases. To find the answer we must compare the postwar years with 1946, which marks, as we have already indicated, the return to a peacetime economy.

\begin{tabular}{ccccc}
\multicolumn{5}{c}{$\begin{array}{c}\text { Indices for wage rates, cost of living, } \\
\text { wholesale prices and net profits }\end{array}$} \\
Year & Wage Rates & $\begin{array}{c}\text { Cost of } \\
\text { Living }\end{array}$ & $\begin{array}{c}\text { Wholesale } \\
\text { Prices }\end{array}$ & $\begin{array}{c}\text { Net Profits } \\
\text { After Taxes }\end{array}$ \\
1946 & 100.0 & 100.0 & 100.0 & 100.0 \\
1947 & 111.6 & 110.0 & 119.0 & 135.0 \\
1948 & 126.2 & 126.0 & 141.0 & 174.3
\end{tabular}

The statistics in the above table are official. They establish a number of very interesting facts:

1. The conclusion drawn above, namely that wages were not at the core of the inflation problem, finds confirmation here, because wage rates increased much less rapidly than the general price index, since 1946.

2. The real wage figure, which is obtained by dividing the nominal wage by the cost of living, has not increased since 1946. In fact, if we divide the wage rate index (which rose to 126.2 in 1948) by the cost of living index (which rose to 126.0), we get 100.1 as an index of the real wage. This means that the workingman could not buy any more goods and services with his 1948 wages than he could with those of 1946 .

Hence it is obvious that, since 1946 at least, wages have done nothing but follow the fluctuations of the cost of living. This parallel is easily explained when we remember that arbitration boards generally accept only a rise in the 
cost of living as a reason for increasing wages, and that they refuse to consider the situation of the business as a whole, except when the company pleads inability to pay.

3. In thus relating wages to living costs we are implicitly acknowledging that the workman's recompense should correspond to the cost of his support. But, strange to behold, in establishing this relation we are all unwittingly verifying the Marxian theory of wages! Almost a century ago, as a matter of fact, Marx declared that in a capitalist system wages were be determined by the cost of the worker's sustenance. If we apply this principle, not only do we hail Marx as a true prophet, but we divorce the worker from the business enterprise and prevent him from profiting in any way from the general economic situation.

4. This does not mean that we should not take account of variations in living costs when fixing wages. The cost of living, as calculated, measures the strict necessities and minimum demands of the workman. And when wages are increased in order to compensate for a rise in living costs, it is obvious that this is not a true increase in the worker's remuneration but simply an adjustment designed to maintain the real wage at a constant level.

5. Actually the most rudimentary justice demands that what the employee receives from his employer correspond to what he (the employee) has given. Wages, in other words, should be proportionate to the value of services rendered. Now the principal criterion for forming a direct and equitable estimate of the value of the worker's services, as of that of the other agents in the productive process, is the value of the output of finished products. In reality it is the price of a given article of merchandise which finally determines the value of the services rendered by those who collaborate in its production. Therefore the value of the finished products should serve to fix wages, as also the remuneration for the other factors in production.

6. In consulting the preceding table we can ascertain the difference in the requirements of the two principles invoked. However, we must note well that the total value of the finished products is not represented in the table. This value is obtained by multiplying the average price by the quantities produced, and our table gives only the price. This limitation is not, however, very important because for the moment we are concerned only with illustrating the principle. Let us sup- pose, then, that in the course of the period studied the rate of production did not change (though actually it did increase), and let us see what results will be obtained.

We have already seen that since 1946 wage increases were decided according to the variations of the cost of living index. As a result of the more or less conscious application of this principle, the wage rate index mounted $26.2 \%$, whereas the value of finished products, as measured by the index in terms of wholesale prices, climbed $41 \%$, which as a result produced an increase of $74.3 \%$ in the net profits.

If, in the period under consideration, wages had been determined by the variations in the value of the finished products they would have increased by $41 \%$, which would have lowered profits about to that level. As any one can see, this system of dividing of profits is much more just than the first one, because it corresponds to the real value of the services of each agent in production.

7. The right of the workers to share in the profits of a business is often put forward these days. This reform is excellent in itself because it implies a democratization of the economic system. From the workman's point of view it would represent an improvement over the present system of payment, which takes account only of the cost of living. However, profit sharing, as far as the worker is concerned, can only give the best results if we apply the principle outlined above, namely that wages be determined according to the value of the finished products. This system does not require, as does the first, a structural reform, and it does not give the impression that from now on the workers will make off with a part of the returns that legally belong not to them but to the owners of the business.

8. When we claim that wage changes should follow the variations of the value of the finished products, we must clearly specify what we mean by the latter expression. It is certainly not to be understood to mean the value of the output of the whole economy, nor that of any particular business establishment taken by itself. It does mean the value of the output of each industry as a whole. So, for example, if it is a question of determining the wages of the employees of the Asbestos Corporation, it is not the general conditions of the national econony nor solely the value of the output of the Asbestos Corporation by itself which must be reckoned with, 
but the general situation in the asbestos industry as a whole.

This procedure is well justified by the following extract from the report of the educational service of the Belgian Christian Trade Union Confederation on "Trade Union Wage Policy":

"Wage policy ought to be based primarily on the total profit of the economic sector involved, not on the total profit of the whole economy nor on that of some firms of abnormal character. Wage earners are interested in the economic situation of their own sector of the economy and not in that of other industries or businesses which have little or no connection with their own, and over which, consequently, they can exercise little or no influence... Wage policy, on the contrary, should as far as possible take account of the average or overall situation of the sector involved. As in everything else, so among business enterprises there are retarded members; the essential thing is not to determine wage levels only by the particular firms in question".

\section{Conclusion}

From all this, one general conclusion stands out. Throughout the period of prosperity and inflation which has been with us since the end of the war, wages have only followed the upward march of the cost of living, and workers have succeeded only in maintaining their former living standard. The working classes cannot tolerate much longer such a situation, which denies them their right to share in economic progress. Such a situation ought to arouse employers' concern as well, for if they wish to fight effectively against Marxism they had better not begin by making it come true in their own industries.

To change this state of things, and to better fulfill the demands of justice, the following suggestions seem imperative:

1. The cost of living index should be used only to determine the minimum raise and the maximum drop in wage changes. The fact that the cost of living would not be the only criterion for fixing wages does not mean that it should not be taken into account. Far from it. The cost of living index in each period measures the needs of the workingman, measures what is necessary for his subsistence. Granted this significance, we can easily see that in a depression period wages cannot fall more rapidly than the cost of living index, whereas in a period of prosperity the rise of the index measures the minimum wage increase that workers are entitled to, because this barely suffices to maintain their standard of living.

2. Beyond this minimum raise and maximum drop in wages as determined by the cost of living index, wages should vary according to the fluctuations in the value of the output of the whole industry concerned. It is definitely the value of output that is meant here, that is to say, the quantities of articles produced multiplied by the average price per unit. Further, it is the value of the whole industry's output and not that of a single firm, no matter whether that firm is more or less prosperous than the average.

Finally, we must take care to divide the value of the output by the number of employees and the work period, which will give as a result the productivity in terms of the number of workers. This procedure is the only one which permits the worker to be paid according to his contribution to the enterprise, and to participate in economic progress, taking full account of the situation of the firm and of the requirements of the common good. Moreover, this method is easy to apply because the Federal Bureau of Statistics publishes every year precise information on the principal characteristics of each sector of industry.

3. To insure the application of these principles in all cases it would be necessary for the provincial government to add a new clause to the act, requiring arbitration boards to take account of the situation of the industry as a whole.

Such a clause is certainly to be desired, for most arbitration boards, often in spite of the evidence at hand, base their decisions entirely on the minimum needs of the worker or the cost of living, and systematically ignore the other parts of the evidence.

A clause of this type would certainly not be unjust. On the contrary, it would very simply oblige arbitration boards to do their duty. They are, in point of fact, charged with the task of determining the just wage, and this depends not only upon the minimum needs of the workingman but also on the situation of the industry and the requirements of the common good.

Finally, this proposition is not without precedent, for the provincial government has for several years now required arbitration boards to take account of the paying capacity of public services, such as municipalities and school boards. 